\title{
(1) Fascia Research 2012: Third International Fascia Research Congress
}

KEYWORDS: Fascia, musculoskeletal manipulation, research, congresses

In October 2007, I opened the First International Fascia Research Congress by noting that the congress was the realization of a dream 30 years in the making. During the 1970s, I completed my residency training in physical medicine and rehabilitation, and the coursework and research training for my doctorate. Those studies taught me to fix muscles, bones, and nerves, and to train new movements and restore function in people with arthritis, stroke, spinal cord injury, amputations, and cerebral palsy (to list just a few). They also exposed me to the underlying principles of physiology, biochemistry, and psychology that guided the clinical treatments. But when it came to connective tissue, all I and my colleagues knew was that, when you heated a rat tail, you could stretch it. There was no other relevant research that I could find. At that moment, three decades ago, I started dreaming of a fascia research congress that would bring together widely separate research disciplines in the service of the clinician.

Every year, publications on fascia in Medline have risen: by 2005, they had reached 600 annually from 100 annually in the 1970s. In reviewing this literature with colleagues in 2005 (that is, reading more papers in a month than you want to see in your entire life), we were able to identify some key leaders in the field, and we extended invitations to those leaders to present at the first congress. To our amazement, almost all agreed immediately to come, although some did not at first realize the connection that their research had to fascia, despite their personal use of manual therapies!

Those of you who attended the 2007 congress (or who own the DVD set) have heard Dr. Frederick Grinnell explain that, despite many years of receiving Rolfing ${ }^{\mathbb{B}}$ Structural Integration, he had no idea that there was any connection between manual therapy and his research until we invited him to be a keynote speaker. The importance of his studies into the shape of the fibroblast cell, which makes up fascia and which can change shape from dendritic to lamellar and back again, is demonstrated in other research presented at the 2007 and 2009 congresses. These related studies show that manual therapies ${ }^{(1)}$, acupuncture $^{(2)}$, and stretching akin to yoga ${ }^{(3)}$ all have an effect on fibroblast morphology, demonstrable at the cellular level.
Interactions between clinicians and researchers form the basis for the fascia congresses. Achieving this interaction was difficult at first, because the National Institutes of Health (NIH) conference grant that supported the first congress required that all clinical presentations be excluded from the NIH-sponsored portion of the conference. The research presentations were not "watered down," and even many scientists struggled to keep up in talks outside their own specific area. Yet both groups hung in, expanding their perspectives until heads were about to explode. This clinician-scientist interaction was reported in Science magazine ("Cell Biology Meets Rolfing"(4)). I myself have watched the DVD recordings 4 or 5 times to develop a more complete understanding of the science and its application to my clinical practice.

When Dr. Peter Huijing agreed to host the second congress in 2009 at his university in Amsterdam, postcongress clinical workshops were added. Again, the congress DVD has allowed me to view the presentations again and again, each time learning something more.

I am pleased to inform the scientists and clinicians alike that this artificial separation will not be necessary at the third fascia congress in Vancouver, March 28 - 30, 2012. Its theme, Fascia Research-What Do We Notice? What Do We Know?, will incorporate dialogue between clinicians and scientists into the conference itself, with each presentation (whether by clinician or scientist) followed by both clinical and science summaries and questions. Post-congress workshops will provide even more opportunity to develop clinical implications or, for those so inclined, research proposals.

As in 2007 and 2009, keynote speakers will present entirely new material. Areas covered will range from basic science to clinical explorations, including mechanical loading and connective tissue change (Al Banes, $\mathrm{PhD}$, University of North Carolina, NC, USA); fluid dynamics in connective tissue remodeling (Rolf Reed, PhD, University of Bergen, Norway); fascial anatomy (Carla Stecco, MD, University of Padua, Italy); repetitive motion disorders (Mary Barbe, $\mathrm{PhD}$, Temple University, PA, USA); myofascial pain (Cesar Fernandez de las Penas, DO, Universidad Rey Juan Carlos, Spain); and clinical trials on manual therapies (Karen Sherman, PhD, University of Washington, WA, USA).

In a sneak preview of some of the information to be presented, I draw from a review of Dr. Reed's studies 
on loose connective tissue and his extrapolation of his findings to remodeling of the connective tissue structure of the heart ${ }^{(5)}$. He was initially interested in the involvement of the extracellular matrix (ECM) in fluid movement between peripheral blood vessels, interstitial fluid, and lymph. He found that this movement is mediated by the extracellular fiber network, with active involvement of connective tissue cells. In acute inflammation, the physical properties of loose connective tissue can change within minutes, resulting in an increase in fluid flow by a factor of more than 100. Reed proposes that "connective tissue cells apply tensile forces on ECM fibers that in turn restrain the under-hydrated ground substance from taking up fluid and swelling," and he has identified a mechanism for collagen gel contraction mediated by fibroblasts and specific integrins and prostaglandins. Thus, loose connective tissue is neither static, nor passive.

Questions to be addressed in 2012:

- Dr. Reed has extrapolated these principles to the heart. Do other tissues respond in a similar way?

- Are there differences in other locations in the body according to the definitions of fascial tissues by Langevin and Huijing ${ }^{(6)}$ presented at the last congress?

- How can these changes be measured, both at the cellular and the gross level?

- How is the fluid flow in the ECM affected by various therapies?

For those of you who have difficulty with the scientific terminology (and I admit to being one of those), let me illustrate the importance of fluid dynamics in another way. A few years ago, I was speaking with Emily Conrad D'aoud, creator of Continuum Therapy. She related some success in working with a woman with paraplegia, and she shared with me a video she had prepared on the progress of this person, who was initially unable to move her legs, but through application of the undulating motion of Continuum, became able to crawl. To my eyes, the client was able to move her arms in such a way as to transmit forces through the fascia of the trunk to the lower extremities. However, Emily's narration spoke of fluid flow, of aligning the client's fluids with the universe. I invited her to present her findings to the spinal cord injury unit at my Veterans Administration Hospital, but insisted that she keep the sound turned off, because I could see no relevance in her fluid theories, and I wanted the team to focus instead on the movement she was able to create. I thought that the fluid theory would make the audience less receptive to the results. The team was duly impressed with her presentation. At the time, I thought that the many sessions of undulating motion were just repetitive practice, allowing the patient to learn some subtle ways of moving. However, in light of Dr. Reed's work, it seems that not only does fascial structure affect fluid flow, it also remodels in response to fluid flow. So perhaps what we were seeing is a restructuring of the fascial tissues in response to the undulatory movements of Continuum. Today, I think that Emily and her generation of clinicians who have developed fascia-oriented therapies are more correct than even they knew. Science is just beginning to catch up with their clinical observations.

In her brilliant paper in the 2009 fascia congress program book, Dr. Denise Hocking used intravital microscopy to show that ECM fibers stretch from muscle cells to nearby arterioles and that, at the beginning of a muscle contraction, these fibers open up a nitric oxide receptor that causes vasodilation and an immediate increase in blood flow to the exercising muscle ${ }^{(7)}$. Although this increase in blood flow with exercise was known by exercise physiologists even when I was studying in the 1970s, the mechanism long escaped any explanation. Scientists had showed that it was not mediated by the brain, by the spinal cord, or by any known hormonal mechanism. Only by considering the role of the ECM and by using advances in scientific techniques could this important physiological mechanism be explored.

Hocking concludes: "Our current study suggests an important new paradigm wherein tensile forces from actively contracting skeletal muscle alter the conformation of fibronectin fibrils surrounding the vascular wall and transiently expose matricryptic FNIII-1 sites that, in turn, initiate a biochemical signal and thus, signal a change in arteriolar diameter. The ability of tissue strain to alter the conformation of fibronectin and expose a cryptic cell-binding domain represents a simple, yet elegant means of converting a mechanical signal into a biochemical response. As such, this novel mechanotransduction pathway may be just one example of a common approach to transmitting mechanical forces, including pulsatile flow and shear stress, from the ECM to cells." These extracellular fibers turn over rapidly, up to $50 \%$ in just 24 hours, again demonstrating an active ever-changing natureand providing another potential mechanism of action for therapies.

To conclude, I share with you some questions prepared by Dr. Carla Stecco in preparation for her keynote address:

It is commonly thought that everything ... to be known about the human anatomy has already been revealed, and that anatomical variables present the only real news in this field. However, if we consider fascial anatomy, nothing is more far from the truth. Indeed, for many years, the fasciae have been considered only as a 'white envelope for the muscles,' and very little attention has been given to their macroscopic and histological anatomy.... We hope to find some answers to 
several rather specific questions concerning fascial anatomy:

- Is deep muscular fascia a dense, regular connective tissue similar to an aponeurosis, as suggested by some authors, or is it an irregular loose connective tissue?

- Inside the deep fasciae can we recognize different regular sublayers, or are the fasciae composed of intertwined bundles of collagen fibers?

- How are the deep fasciae related with the underlying muscles?

- Does the superficial fascia exist? Does it have a specific structure, or not?

- How do the various fasciae appear under ultrasound, MRI, and CT scans? Could these instruments help us to understand the structure of the fasciae in living people? And what about the relationship between fasciae and surrounding structures?

- What is the role of the ECM, and in particular of the hyaluronic acid component?

- Could fasciae be considered elastic tissue? What is the percentage of elastic fibers within fasciae? Are there regional variations?

- Are fasciae innervated? And what type of receptors could be recognized within fasciae?

- What is the relationship between the fasciae and muscle spindles?

- Do the fasciae possess a basal tonus?

- Do fasciae have the capacity to actively contract?

- Do fasciae have a role in proprioception and in peripheral motor coordination?

Answers to these questions could contribute to clinician's understanding of the biomechanical behavior of the fasciae, their role in acute and chronic myofascial pain syndromes and of the real effectiveness of different therapies.

I encourage readers to review the definitions of fascia proposed by Langevin and Huijing, and to come to the congress with specific questions in which the specific fascial structure of interest is defined. As proposed by those eminent scientists, those structures are the dense connective tissue, the areolar connective tissue, the superficial fascia, the deep fascia, the intermuscular septa, the interosseal membrane, the periost, the neurovascular tract, the epimysium, the intra- and extramuscular aponeuroses, the perimysium, and the endomysium. The full article is available online at http://www.ijtmb.org/index.php/ijtmb/article/view/63/80.

And so, clinician and scientist alike, I invite you to share your observations and to participate in yet another exciting conference to be held March 28-30, 2012, in Vancouver, British Columbia, Canada. Registration for the Third International Fascia Research Congress (Fascia Research-What Do We Notice? What Do We Know?) opens March 1, 2011, with abstract submissions due by July 1, 2011.
Pre- and post-congress workshop descriptions, program details, and information on ordering the program books and DVDs from previous congresses can be found at http://www.fasciacongress. org/2012. The program book for 2012 will include full-text scientific papers (some new; some older, but forgotten) presenting entirely new research that expands the basis for the scientific study of fascia, and abstracts of the latest research to be presented in papers and posters. The program book for each congress includes materials that are entirely different from those in previous congress books; the content encompasses a careful selection of the latest scientific literature that is most important for fascia research (and which is still somewhat readable for people outside that immediate field). A summary of 2007 program book is available online ${ }^{(8)}$, as is a summary of the 2009 book $^{(9)}$.

\section{CONFLICT OF INTEREST NOTIFICATION}

The author declares that there are no conflicts of interest.

\section{COPYRIGHT}

Published under the CreativeCommons AttributionNonCommercial-NoDerivs 3.0 License.

\section{REFERENCES}

1. Standley P. Biomechanical strain regulation of human fibroblast cytokine expression: an in vitro model for myofascial release? In: Findley TW, ed. First International Fascia Research Congress [DVD]. Vol. 1. Boulder, CO: Ida P. Rolf Research Foundation; 2007.

2. Langevin H. Dynamic connective tissue fibroblast cytoskeletal response to tissue stretch and acupuncture. In: Findley TW, ed. First International Fascia Research Congress [DVD]. Vol. 1. Boulder, CO: Ida P. Rolf Research Foundation; 2007.

3. Langevin HM, Bouffard NA, Fox JR, Barnes WD, Wu J, Palmer BM. Fibroblast cytoskeletal remodeling contributes to viscoelastic response of areolar connective tissue under uniaxial tension. In: Huijing PA, Hollander P, Findley TW, eds. Second International Fascia Research Congress [DVD]. Vol. 1. Boulder, CO: Ida P. Rolf Research Foundation; 2009.

4. Grimm P. Biomedical research. Cell biology meets Rolfing. Science. 2007;318(5854):1234-1235. [Available online at http://www.fasciacongress.org/318.1234.Grimm.pdf]

5. Reed RK, Lidén A, Rubin K. Edema and fluid dynamics in connective tissue remodelling. $\mathrm{J} \mathrm{Mol} \mathrm{Cell} \mathrm{Cardiol.}$ 2010;48(3):518-523.

6. Langevin HM, Huijing PA. Communicating about fascia: history, pitfalls, and recommendations. Int J Ther Massage Bodyw. 2009;2(4):3-8. http://www.ijtmb.org/index.php/ ijtmb/article/view/63/80. Published December 2009. Accessed 
November 30, 2010.

7. Hocking DC, Titus PA, Sumagin R, Sarelius IH. Extracellular matrix fibronectin mechanically couples skeletal muscle contraction with local vasodilation. In: Huijing PA, Hollander P, Findley TW, Schleip R, eds. Fascia Research II: Basic Science and Implications for Conventional and Complementary Health Care. Munich, Germany: Elsevier Urban and Fischer; 2009: 129-137.

8. Findley T. Second International Fascia Research Congress. Int J Ther Massage Bodyw. 2009;2(2):1-6. http://www.ijtmb. org/index.php/ijtmb/article/view/52/63. Published June 2009. Accessed November 30, 2010.
9. Findley T. Fascia Research II: Second International Fascia Research Congress. Int J Ther Massage Bodyw. 2009;2(3):4-9. http://www.ijtmb.org/index.php/ijtmb/article/view/61/70. Published September 2009. Accessed November 30, 2010

Thomas Findley, MD, $\mathrm{PhD}$ Editor-in-Chief, IJTMB Center for Healthcare Knowledge Management New Jersey Veterans Healthcare System Professor, Department of Physical Medicine and Rehabilitation University of Medicine and Dentistry of New Jersey East Orange, NJ, USA 